\title{
Occupational diversification in Jammu and Kashmir: A sectoral analysis
}

\author{
Arshid Ahmad Mir and Tariq Ahad Nengroo \\ Research Scholars, Department of Economics, University of Kashmir, Jammu and Kashmir
}

\begin{abstract}
The paper examines the occupational pattern in Jammu and Kashmir. This paper has made a sectoral analysis in light of trend in employment share over a period of time. The evidence for occupational diversification and structural changes in Jammu and Kashmir has been confirmed by the data figures from census and NSSO data. The movement of labour force from primary sector has been absorbed by the service sector in the process of structural changes in state economy. More so, the secondary sector failed to mature fully and create sufficient job opportunities, as it has more employment elasticity. Thus state followed the national pattern of bypassing the industrial sector in the process of development.
\end{abstract}

Keywords: Occupational diversification, employment elasticity, Jammu and Kashmir

\section{INTRODUCTION}

The structural transformation is often equated with the decline in primary sector share in GDP. More so, the share of labour force declines from agriculture sector while increases in industrial and tertiary sectors (occupational diversification). Diversification in sources of income, change in employment structure and income brackets are few outcomes of development. However inequality in endowments in terms of access to assets, segments of labour market based on wage difference and limited opportunity in context of rural areas, ends up with benefitting few endowed people. The structural transformation in an economy creates favorable chance for all sectors in the economy to excel. As the development gets momentum, non-farm sector comes up with more job avenues for qualified youth particularly in urban areas. But the jobs created during the process remain very limited in relation to labour supply. The recent growth experience of Indian economy brought some dynamism in rural labour markets in the shape of mechanization of agriculture, rural-urban associations and improvement in labour skills and qualifications. However information lag, low access and fewer opportunities are common features of rural labour markets. Thus very few endowed people enjoy the benefits of rural labour market diversification. Major share of rural population is pushed into certain lowwage segments in the rural economy. More so rural labour markets are visible examples of low productivity, inferior jobs and low wages and ends up with increased levels of poverty and other deprivations. These factors in turn results in widening gap in earnings between sectors and regions In line with segmentation of labour market. The poverty level in rural India is 33.3 percent, while it is higher among farm labour (49.4\%) followed by non-farm labour $(39.6 \%)$, self-employed in non-farm sector (28\%), self-employed in agriculture (26.2\%) and regular employed (14.4\%) (Krishna A and Shariff A. 2011).

There is no doubt that implication of structural transformation has been visible in Jammu and Kashmir economy. The share of primary sector has declined to $16.67 \%$, while share of industrial sector and service sector has increased to $27.26 \%$ and $56.07 \%$ respectively as per directorate of economics and statistics J\&K 2017. Besides the changes in sectoral share in GSDP, changes in occupational shares among sectors also reflect the structural change in economy. Structural changes in occupational pattern in rural and urban areas can be analyzed from the table below during the period from 1993-2012. 
International Journal of Research in Advent Technology, Vol.7, No.4, April 2019

E-ISSN: 2321-9637

Available online at www.ijrat.org

Table 1: Percentage Distribution of Workers in the Principal Status by Broad Industry Division:

\begin{tabular}{|c|c|c|c|}
\hline Year & Sector & Rural & Urban \\
\hline \multirow{2}{*}{$1993-94$} & Primary & 64.1 & 8.0 \\
& Secondary & 16.1 & 18.1 \\
& Tertiary & 19.5 & 73.8 \\
\hline \multirow{2}{*}{$1999-00$} & Primary & 66.7 & 10.7 \\
& Secondary & 15.3 & 22.5 \\
& Tertiary & 17.9 & 66.6 \\
\hline \multirow{2}{2007-08}{} & Primary & 49.9 & 6.6 \\
& Secondary & 22.7 & 25.3 \\
& Tertiary & 27.5 & 68.1 \\
\hline $2011-12$ & & & 5.2 \\
& Primary & 45.11 & 25.0 \\
& Secondary & 24.74 & 69.8 \\
\hline
\end{tabular}

Source: NSSO Various Rounds.

The development process in state has resulted in change in employment pattern among sectors of $\mathrm{J} \&$ $\mathrm{K}$ economy. The numerical figures from table 1 reveal that in rural areas, employment share of primary sector has declined from 64.1 to 45.11 during 1993-2012. However primary sector still emerges as a main sector in terms of labour absorption in rural areas. Primary sector has a meager share in urban employment. The primary sector in terms of urban employment is just $5.2 \%$ (2011-12) as indicated above. The pace of industrialization is so slow in the state that it did not show any significant mark on the occupational distribution. The industrial sector has not been in a position to generate sufficient jobs in both regions and thereby failed to absorb the transferred labour force. The service sector has always remained at fore front in terms of employment in urban areas and slowly giving the place to rural labour force. Tertiary sector employment share has increased to 30.15 and 69.8 in rural and urban areas respectively. The population structure of Jammu and Kashmir is more skewed towards rural population with $72.63 \%$ of rural share out of total population. More so Rural poverty is about $11.5 \%$ which is higher than the state level average i.e. $10.4 \%$. In the above backdrop, Jammu and Kashmir rural sector suggests that we need to take more serious look for generating non-farm employment opportunities for rural population. Occupational diversification is much needed to keep the pace with growing population and household needs.

\section{LITERATURE REVIEW}

K. Sivasubramaniyan (2017) the study examined the sectoral employment share in Tamil Nadu from last 60 years. The study found the declining trend of employment share in agricultural sector, however still dominates the other two sectors. The study unveiled the result that industrial sector could not generate enough job opportunities. Similar pattern has been followed by Karnataka and Andhra Pradesh. The author recommended the technological improvement and population control to overcome the barriers for growth and development.

Bagchi, Das and Chattopadhyay (2005) analysed the structural changes in Gujarat during 1970 to 2000 by using $F$ test and $T$ test. The researchers revealed that agricultural sector could not modernize hence became victim of stagnation and decline. However industrial and service sector have accelerated the growth process and employment generation. It is worth to mention that organized sector could not increase the employment share during the period.

Gaurav Sehgal and Prof. Ashok Aima (2014) analysed the structural changes in Jammu and Kashmir in shape of employment share in various sectors of economy. The study found that occupational shift has been seen from agricultural sector to service sector without development in secondary sector, which provides more employment opportunities. The study found the agricultural backwardness the reason for lower employment opportunity in the sector. More so, the industrial sector fuels the problem of unemployment rate, thus leading to lower employment opportunities for the jobless youth of the state. 


\section{METHODOLOGY}

The study is based on the secondary data analysis. The data has been retracted from various sources like NSSO, Census, Labour surveys etc. The result and conclusion has been drawn on the basis of the data inferences and analysis.

\section{Labour assimilation in primary sector:}

The agricultural economic contribution to GSDP of Jammu and Kashmir is steadily declining; still agriculture emerges as a major sector and plays a vital role in socio-economic fabric of the state. Nominal progress has been achieved in the secondary as well as in tertiary sector. Agriculture being the dominant sector sustains livelihood of $70 \%$ of the population. However productivity in agriculture is very low in relation to other states and rest of the country. The share of agriculture and allied sectors in the GSDP is estimated only $16.67 \%$ for the year 2011-12 as per (Directorate of Economics and Statistics J\&K). It is well established fact agriculture sector is overcrowded in Rural Jammu and Kashmir because more than $70 \%$ of population are directly or indirectly linked to agricultural sector. Therefore labour absorption in the agriculture sector is already strained. The increasing mechanization of agriculture, successive land division results in marginal land holdings, use of capital intensive techniques, in sum and substance may possibly restrict the employment possibility in agriculture sector. However it is worthy to note that like the national pattern, Jammu and Kashmir GSDP share of primary sector has shown tendency to decline. But the primary sector in the state is still dominant sector in terms of employment share. From the table 2 below it is evident that Agriculture and allied sectors occupy $43.00 \%$ share of employment in the state. Hence dominates in terms of labour absorption share. Horticulture has a substantial a substantial share in the Gross State Domestic product. Kashmiri horticulture crops particularly apple, walnut, almond and apricot are famous. It absorbs large chunk of people during the various stages and processes. These crops are more skewed towards rural areas thus acts as better sources for employment and income for rural areas. Live stock has been adopted as a subsidiary occupation by majority of rural population. It provides employment opportunities and better economic returns for rural population particularly in rural hilly areas. It is worth to mention that the state is highly endowed with high potential for fisheries. Since 1972 labour force participation has increased from 5466 to 13172 till 2003 in fisheries. Thus fisheries emerged as an alternative source for employment and income particularly for rural population. However keeping in view the population stress in agricultural sector, low productivity, rural poverty, increasing marginal land holdings and low agricultural price occupational diversification is much needed in the state especially among rural areas. The increasing marginal land holding at the state and national level is a cause of concern for policy makers. The government of India has announced a scheme in the agriculture sector "Pradhan Mantri Kisan Samman Nidhi" in the recent interim budget 2019-20. The scheme will entail payment of 6,000 annually. The scheme will benefit each of the 12 crore marginal farmers in the country (interim budget 2019). Along with these schemes we need to focus on positive some investments which will have more potential for employment generation and a step forward for rural diversification.

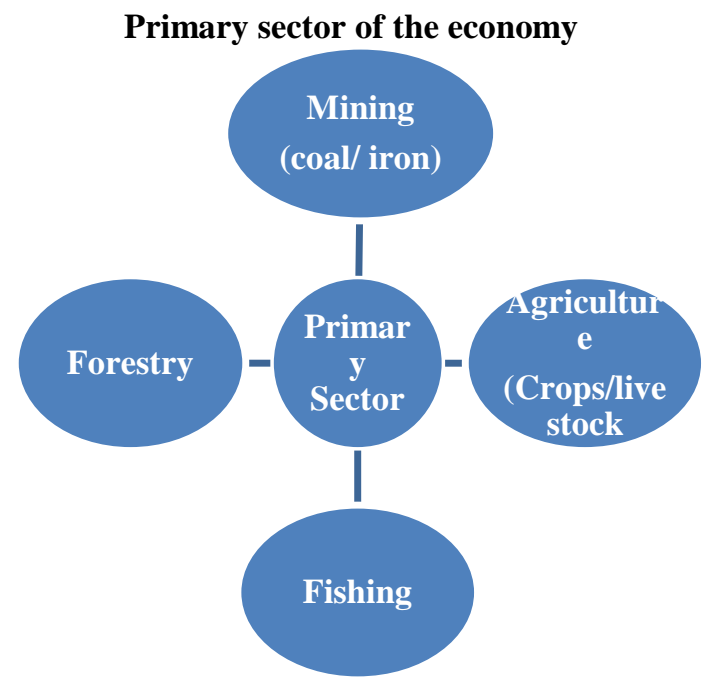




\section{International Journal of Research in Advent Technology, Vol.7, No.4, April 2019 E-ISSN: 2321-9637 \\ Available online at www.ijrat.org}

It is an utmost necessity that a good number of labour force in agriculture sector need to be migrated to industrial and tertiary sector. Such transfers will result in rising per labour productivity. Productivity in non-farm sectors is usually higher than the agricultural sector. The transference of workers from low to high productivity sector will result in higher GSDP. The growth in GSDP will in turn increase the per capita income, provided the population growth happens within limits or the GSDP growth rate keeps pace with the addition in population. More over the occupational diversification will help to minimize risks of livelihood failures. It diversifies the sources of income particularly solves the problem of marginal land holders and people without ownership title of any land asset.
Labour absorption in industrial sector:

The industrial sector is of paramount importance as it speeds up growth process, generates more employment, plays a greater role in commercialization of agricultural and also creates some positive spillover effects in the economy. Industrialization is needed to meet the developmental demands in the economy. More so, industrial sector provides linkages to the primary sector along with generating the sufficient jobs in the economy, so as to meet the labour supply.

There has been a missing link in Jammu and Kashmir of the secondary sector, for creating the agricultural linkages and has failed to generate enough jobs in an era of accelerated growth rates. The state of Jammu and Kashmir is following the national pattern of lower contribution of Industrial sector to GSDP and snail pace in employment generation. Industrial sector in Jammu and Kashmir provides a gloomy picture in terms of labour absorption.

Table 2: Sectoral occupational structure (percentage)

\begin{tabular}{|c|c|c|c|}
\hline Year & Primary Sector & Secondary Sector & Tertiary Sector \\
\hline 1961 & 78.62 & 9.03 & 12.35 \\
\hline 1971 & 71.05 & 8.94 & 20.01 \\
\hline 1981 & 64.28 & 14.27 & 21.45 \\
\hline 1991 & 57.19 & 10.24 & 32.58 \\
\hline 2001 & 50.10 & 6.20 & 43.70 \\
\hline 2011 & 43.00 & 8.00 & 49.00 \\
\hline
\end{tabular}

Source: Various census reports.

The above table reveals the fact that primary sector has been showing declining trend for labour absorption as its share has declined from 78.62 in 1961 to just 43.00 in 2011 . It is worth to mention that secondary sector could not absorb the satisfactory labour force retracted from primary sector. Primary sector labour absorption has increased from 9.03 in 1961 to 14.27 in 1981 , however declined thereafter till it stabilized at 8.00 in 2011 . From table 1 above, the figures at rural and urban level also confirms that secondary sector could not attract the people. The rural labour force percentage in industrial sector has slightly increased from $16.1 \%$ in $1993-94$ to 24.74 in 2011-12. More so in urban areas employment percentage in secondary sector has improved from $18.1 \%$ in $1993-94$ to $25.0 \%$ in $2011-12$. Thus it is evident from the discussion that secondary sector has failed to generate enough employment opportunities for the labour force who have transferred from the primary to other sectors of economy at regional as well as state level. Service sector has bypassed the industrial sector in employment generation and labour absorption. It has created ample opportunity for labour absorption as its employment share has increased from 12.35 in 1961 to satisfactory level of 49.00 in 2011 from table 2.

\section{Service sector labour employment:}

The service sector has emerged as a major sector in terms of contribution to GSDP, providing employment and public services for the economy. Development of nation is accelerated by the performance of tertiary sector as proposed by Collin Clark, Simon Kuznets etc. Service sector mainly comprises transport, communication, education, health and banking, insurance etc. The state of Jammu and Kashmir is worst hit by unemployment as the state has the highest unemployment rate of $5.3 \%$ as per NSSO $68^{\text {th }}$ round $2011 / 2012$. The service sector in the state has been main booster of growth rate and in creation of jobs. The above table 2 unveiled that labour movement from the primary sector has been skewed towards service sector. Occupation share of service sector has persistently increased from 12.35 in 1961 to 49.00 in 2011. More so, occupational percentage of service sector at 


\section{International Journal of Research in Advent Technology, Vol.7, No.4, April 2019 E-ISSN: 2321-9637 \\ Available online at www.ijrat.org}

regional level i.e. rural and urban percentage has also increased as per table 1 . From the table 1 it is evident that rural percentage of labour force has increased from $19.5 \%$ in 1961 to $30.15 \%$ in $2011-12$. Service sector employment share in urban area has stabilized at $69.8 \%$ in $2011-12$

\section{CONCLUSION}

Occupational structure in Jammu and Kashmir is more skewed towards service sector. Urban area is dominated by service sector in providing employment with $69.8 \%$ share out of total employment in urban areas. However rural areas are more inclined towards primary sector with $45.11 \%$ rural employment share in 2011-12. Wave of structural transformation has been experienced in the state, which is evident by the fact that primary sector share in GSDP and employment is declining where as secondary and service sector is taking over the control on economy. It worth to be noted that even though Jammu and Kashmir state is agrarian economy in nature, still diversification, transformation and structural shift in economy is visible. The share of primary sector has declined to $16.67 \%$, while share of industrial sector and service sector has increased to $27.26 \%$ and $56.07 \%$ respectively as per directorate of economics and statistics J\&K 2017. Though the state is an agrarian economy still primary sector employment share has been on decline. Primary sector employment share has decreased from $78.62 \%$ to $43.00 \%$ from 1961 62 to 2011-12; Service sector employment has been expanding and is playing a more dominant role in employment share with 49.00 in 2011-12. The fact cannot be denied that secondary sector which has higher employment elasticity has failed to generate sufficient job opportunities in the state. It has a meager employment share of $8 \%$ at state level (Census). Therefore secondary sector provides an ample opportunity for large scale job creation.

The sectoral analysis and development experience of Jammu and Kashmir raises some debatable questions. Despite the fact that agricultural sector is the backbone of the state however it has become victim of backwardness, stagnation and craves for mechanization and technological advancement. More so, secondary sector in Jammu and Kashmir has been passive in the course of development, thus failed to generate sufficient job opportunities for the unemployed youth of the state. Though the tertiary sector is performing better within the state however, as compared to neighboring northern states like Punjab, Himachal Pradesh and Haryana, service sector is under performing. In sum and substance, a major policy initiative is needed to overcome the hurdles in the way of sustainable development of the state.

\section{REFERENCES}

[1] A Reddy (2014) "Rural labour markets: insights from Indian villages" Asia - pacific journal of rural development July 2014

[2] Aasif Nengroo (2015) "employment and unemployment scenario of Jammu and Kashmir" international journal of scientific research in science and technology

[3] Bhalla et al., (1997) "Recent development in Indian agriculture: A state level analysis" planning of India, Economic and political weekly.

[4] B Qadri and M Kasab (2017) "Educational unemployment in Jammu and Kashmir: Causes, consequences and remedial measures" Asian journal of managerial science.

[5] Das. N (2004) "Low employment growth, reviving labour intensive manufacture" economic and political weekly, Vol. No. 39 p. 2192-2194

[6] Hurmat Sumaiya et al., (2018) "Occupational structure and economic development from 198990 to 2013-14: A case study of Jammu and Kashmir economy" Journal of humanities and social science (IOSR-JHSS) vol. 23. 1, 2018, pp. 35-39

[7] K. Sivasubramaniyan (2017) "Sectoral contribution and their relevance in India: with special reference to three south Indian states" International Journal of Research, Granthaalayah, 5(9), 116-123.

[8] NSSO 68TH Round, (various years) "Survey on Employment and Unemployment" National Sample Survey Organization, Ministry of Statistics and program Implementation Government of India

[9] Digest of statistics, (2011) "Directorate of Economics and Statistics government of Jammu and Kashmir".

[10] Interim budget 2019: https://www.indiabudget.gov.in/ub2019$\underline{\text { 20/bs/bs.pdf }}$ 